\title{
Physical, chemical and mineralogical characterisation of hydraulically disposed fine coal ash from SASOL Synfuels
}

\author{
Jabulani S. Mahlaba ${ }^{\text {a,b,* }}$, Elsabé P. Kearsley ${ }^{a}$, Richard A. Kruger ${ }^{c}$ \\ ${ }^{a}$ University of Pretoria, Civil Engineering, Pretoria, South Africa \\ ${ }^{\mathrm{b}}$ SASOL Technology RED, Environmental Science and Engineering, Secunda, South Africa \\ ${ }^{\mathrm{c}}$ Richonne Consulting, P.O. Box 742, Somerset Mall, Cape Town, South Africa
}

\section{A R T I C L E I N F O}

\section{Article history:}

Received 22 October 2010

Received in revised form 14 March 2011

Accepted 16 March 2011

Available online 26 March 2011

\section{Keywords:}

Coal combustion by-products

Fine coal ash dam

C-S-H gel

Chemical weathering

Hydration products

\begin{abstract}
A B S T R A C T
Coal serves as the primary energy source in most parts of the world. It is a fact that coal combustion yields enormous quantities of fly ash some of which are either hydraulically placed or dry dumped. The current study attempts to provide a comprehensive characterisation of a disused alkaline fine coal ash dam (FCAD) towards assessing environmental impact, rehabilitation and utilisation potential. Fine coal ash refers to a combination of approximately $83 \%$ power station fly ash and $17 \%$ gasification and bottom ash fines (particles $<250 \mu \mathrm{m}$ ) at SASOL Synfuels. The hydration products found in Weathered Fine Coal Ash (WFCA) using X-ray Diffraction (XRD) and Differential Scanning Calorimetry (DSC) are analcime, calcite, C-S-H gel, ettringite, hydrated gehlenite (Strätlingite), magnetite, periclase, pyrrhotite and sillimanite. High resolution Scanning Electron Microscope (SEM) results provide additional proof that hydration products are present in WFCA. No indication of appreciable leaching was given by X-ray Fluorescence (XRF) results except calcium and silicon. Thus evidence exists that pollutants from saline brines are immobilised in WFCA and an insight of reaction kinetics was obtained. High content of amorphous phase and lack of alteration in some geotechnical properties suggest that WFCA can be reutilised with lime addition to increase alkalinity and activate pozzolanic reactions.
\end{abstract}

(c) 2011 Elsevier Ltd. All rights reserved.

\section{Introduction}

South Africa and many other countries rely on coal as a primary source of energy. The coal combustion process yields vast quantities of fly ash, the majority of which is disposed of either in dry or slurry form. Environmentalists and the public have a concern about coal ash despite its utilisation applications which include addition in cement and concrete manufacturing, agriculture, and waste stabilisation [1-11]. Furthermore, ash utilisation only consumes a small fraction of total fly ash production leaving the majority for internal disposal or landfilling. The latter is increasingly becoming more costly [11] while the former necessitates rehabilitation before site closure which is also expensive.

Several researchers have investigated the effect of chemical weathering on dumped ashes mainly from a geochemical point of view and most concluded that coal ash leaches heavy metals [12-15]. However, no literature covering comprehensive characterisation of dumped ash was found while researchers such as Lee et al. [16], Koch [17] and Sarkar et al. [18] only studied certain aspects.

* Corresponding author at: SASOL Technology R\&D, Environmental Science and Engineering, Secunda, South Africa. Tel.: +27 (0)17 619 2500; fax: +27 112192858

E-mail address: sam.mahlaba@sasol.com (J.S. Mahlaba).
A study was conducted at the University of Pretoria to investigate the weathering of hydraulically disposed fine ash at SASOL Synfuels, which consumes over 45 million tons of coal and yield over 4 million tons of fine ash per annum. Fine coal ash refers to a combination of approximately $83 \%$ power station fly ash and $17 \%$ made up of both gasification ash and bottom ash fines (particles $<250 \mu \mathrm{m}$ ). It was impractical to obtain fresh fine ash in dry form because it results from the thickening of hydraulically removed ashes. The gasification and power generation processes of SASOL Synfuels use the same coal feedstock, which suggests similar chemical compositions [19]. The mineralogy of gasification ash [20] is comparable to that of fly ash under different burning conditions. It was therefore justified to use fresh fly ash as a control in this investigation.

The purpose of this manuscript is to present geotechnical, chemical and mineralogical results of a fine coal ash dam in comparison to fresh fly ash. It is believed that such an understanding is beneficial towards identifying suitable rehabilitation methods, environmental assessment and utilisation opportunities.

\section{Site and materials}

Core samples were collected from a 16-year old fine ash dam of SASOL Synfuels in Secunda, South Africa. A hydraulic ash disposal 
system is employed where fine ash interacts with saline brines (with a typical salinity of $8,000 \mathrm{mg} / \mathrm{L}$ ) in the form of slurry with a specific gravity of 1.3. Several discharge points of slurry across the fine coal ash dam (FCAD) are interchangeably used during the construction of a FCAD shown in Fig. 1. Five boreholes were drilled in areas designated as BH1, BH2, A5, E4 and F4 in Fig. 2; a black spot represents the penstock.

The samples were collected vertically from the aforementioned boreholes using an Auger drill. The material collected over $1.5 \mathrm{~m}$ lengths was blended to make up a set of samples for the whole $50 \mathrm{~m}$ depth. The sampling method was best suited for the intended investigation and safety of the dam. It must be noted that there are five FCADs in the complex two of which were superficially investigated by Koch [17]. The present investigation attempts to provide comprehensive characterisation of a FCAD which was never investigated before due to access restrictions.

\section{Methods}

The physical characterisation which was conducted included the determination of natural Moisture Content (MC), Particle Size Distribution (PSD) and Specific Gravity $\left(G_{\mathrm{s}}\right)$. The MC determination was based on mass loss during drying at $110 \pm 5{ }^{\circ} \mathrm{C}$ to a constant mass in accordance with ASTM D2216-98 [21]. A Malvern Mastersizer was used to determine PSD while $G_{\mathrm{s}}$ was determined using a Le Chatelier flask. Pore water was extracted by thoroughly mixing dried sample with deionised water and leaving it to stand for $60 \mathrm{~min}$ before $\mathrm{pH}$ and electrical conductivity (EC) were recorded. It was performed according to ASTM D4972-01 [22] except that the solid-to-liquid ratio was adjusted to $1: 2(\mathrm{w} / \mathrm{w})$ to suite material properties. Chemical composition and mineralogy were determined using X-ray Fluorescence (XRF), X-ray Diffraction (XRD), Differential Scanning Calorimetry (DSC), and Field Emission Gun Scanning Electron Microscopy (FEG-SEM). The samples were pressed as briquettes and introduced to the ARL 9400XP + XRF and analysis was based on UniQuant software. XRF results were normalised with a respective loss-on-ignition (LOI) value, which was $4 \%$ in fly ash. XRD data were collected using a PANalytical X'Pert Pro powder diffractometer with $\mathrm{X}^{\prime}$ Celerator detector and variable divergence and

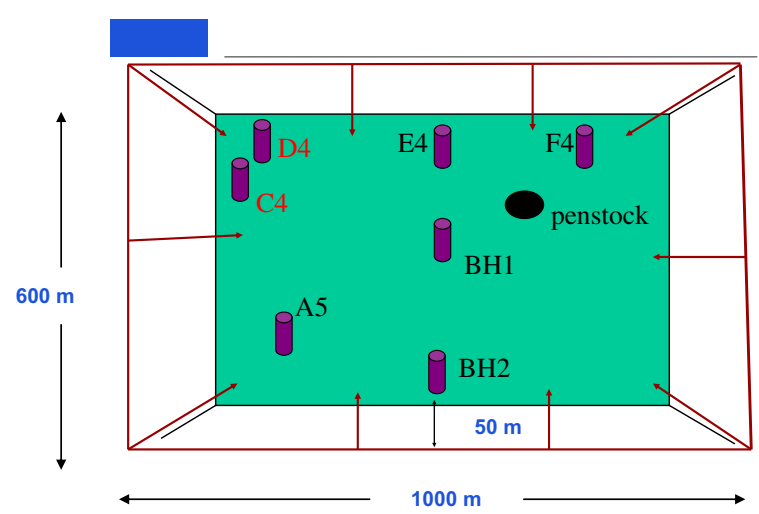

Fig. 2. The layout of FCAD.

receiving slits with Fe filtered $\mathrm{Co} \mathrm{K} \alpha$ radiator. The phases were identified using $\mathrm{X}^{\prime}$ Pert Highscone plus software. 20\% Si (Aldrich 99\% pure) was added to samples which were then milled in a McCrone micronising mill for the determination of amorphous content. The relative phase amounts were estimated using the Rietveld method (Autoquan Program). Thermal analysis was performed on a Mettler Toledo DSC $822^{\mathrm{e}}$ Star $^{\mathrm{e}}$ System with an FRS5 sensor. The heating rate was $10^{\circ} \mathrm{C} / \mathrm{min}$ from $25^{\circ} \mathrm{C}$ to $150^{\circ} \mathrm{C}$, cooling from 150 to $25^{\circ} \mathrm{C}$ at $20^{\circ} \mathrm{C} / \mathrm{min}$. The second heating from 25 to $500{ }^{\circ} \mathrm{C}$ was again at $10^{\circ} \mathrm{C} / \mathrm{min}$ and final cooling was at $20^{\circ} \mathrm{C} / \mathrm{min}$. A Zeiss ULTRA plus 55 FEG-SEM with InLens detector was operated at $1 \mathrm{keV}$ to analyse surface properties on the carbon-coated samples.

\section{Results and discussion}

\subsection{Particle size distribution}

The PSD of ash was classified into clay-, silt- and sand-sized particles according to ASTM D422-63 [23] where:

Clay-sized particles $=$ particles greater than $1 \mu \mathrm{m}$ and smaller than $5 \mu \mathrm{m}$

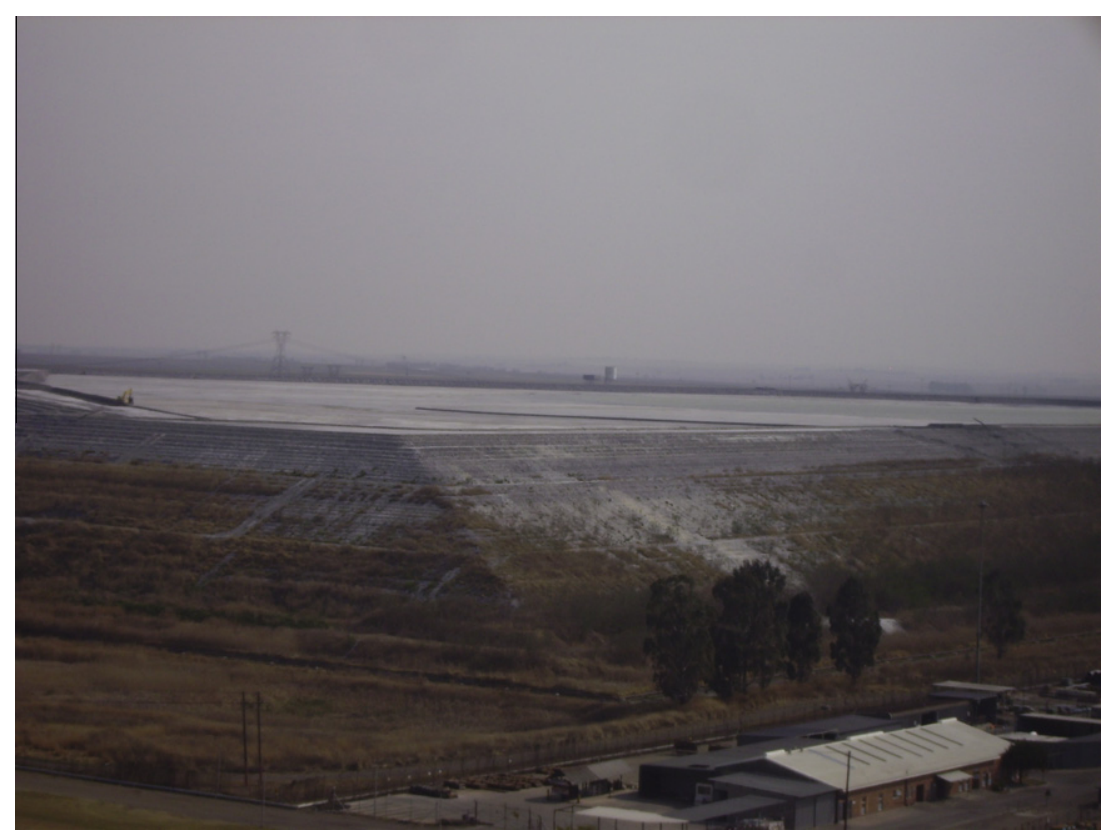

Fig. 1. The side view of a FCAD. 
Silt-sized particles $=$ particles greater than $5 \mu \mathrm{m}$ but smaller than $75 \mu \mathrm{m}$

Sand-sized particles $=$ particles greater than $75 \mu \mathrm{m}$ but smaller than $425 \mu \mathrm{m}$

The summary of PSD data presented in Table 1 demonstrates that the PSD of Weathered Fine Ash (WFCA) is very similar to that of fly ash but varies over a wider range. However, there is huge variation in the overall data, which is attributed to plant disruptions such as boiler efficiency $[2,24]$ but no proper records exist for verification. The nature of variation of PSD in the FCAD and its resemblance to fly ash is illustrated in Fig. A1 (in Appendix A).

It is therefore concluded that WFCA is silty-clayey and has a characteristic PSD profile, which negates hydraulic sorting principle as observed in the gold tailings where locations near discharge points are coarser $[25,26]$. The possible explanation of this distinction is that fine coal ash has a predominantly spherical morphology which promotes flowability [2].

\subsection{Specific gravity}

Specific gravity $\left(G_{\mathrm{s}}\right)$ was determined and results indicate no substantial difference between WFCA and fly ash as shown in Fig. 3. The values of $G_{s}$ vary from 2.0 to 2.2 in WFCA while that of fly ash was found to be 2.2. The implications are that settling and workability of WFCA and fly ash should remain similar in as far as particle velocity due to gravity is concerned.
Table 1

Summary of PSD data.

\begin{tabular}{llll}
\hline Particle size & WFCA $^{\text {a }}$ & Median & Fly ash \\
\hline Clay-sized (\%) & $5-77$ & 16 & 14 \\
Silt-sized (\%) & $23-83$ & 60 & 59 \\
Sand-sized (\%) & $0-64$ & 30 & 27 \\
$D_{50}(\mu \mathrm{m})^{\mathrm{b}}$ & $3-120$ & 23 & 27.5 \\
\hline
\end{tabular}

a WFCA $=$ weathered fine ash.

b $\mathrm{D}_{50}$ is defined as the diameter of sieve through which $50 \%$ of particles pass.

\subsection{Moisture content}

The MC presented in Fig. 4 demonstrates that the degree of wetness increases with depth for most boreholes. MC predominantly lies between $27 \%$ and $37 \%$ which indicates a high water holding capacity, likely to sustain hydration reactions.

\subsection{Pore water quality}

The $\mathrm{pH}$ of pore water has an average value of 9.5, which is three units lower than $\mathrm{pH} 12.5$ of fresh fly ash (Fig. 5). M-alkalinity was dramatically reduced from 1800 in fly ash to approx. $50 \mathrm{mg} / \mathrm{L}$ as $\mathrm{CaCO}_{3}$ in WFCA. A review by Donahoe [27] reports that this major drop in $\mathrm{pH}$ is caused by carbonation, hydrolysis and precipitation (called chemical weathering) after the depletion of portlandite $\left(\mathrm{Ca}(\mathrm{OH})_{2}\right)$.

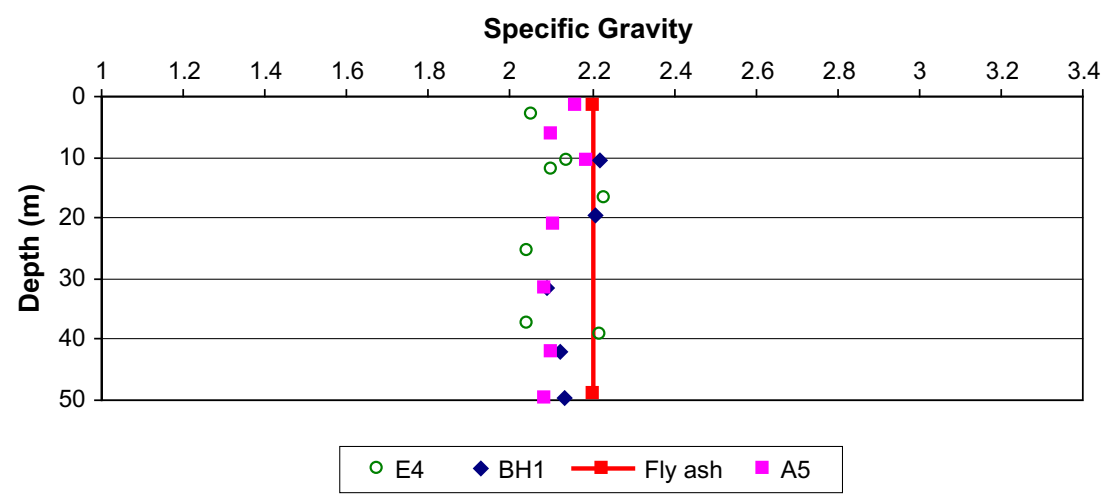

Fig. 3. The specific gravity of WFCA and fly ash.

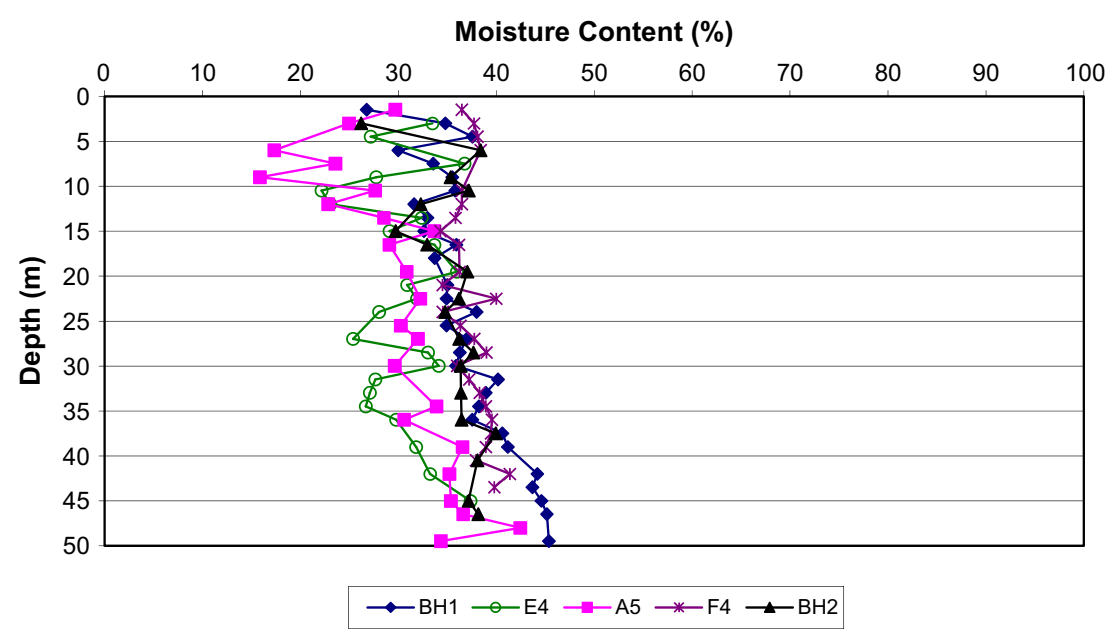

Fig. 4. Moisture content profile of FCAD. 


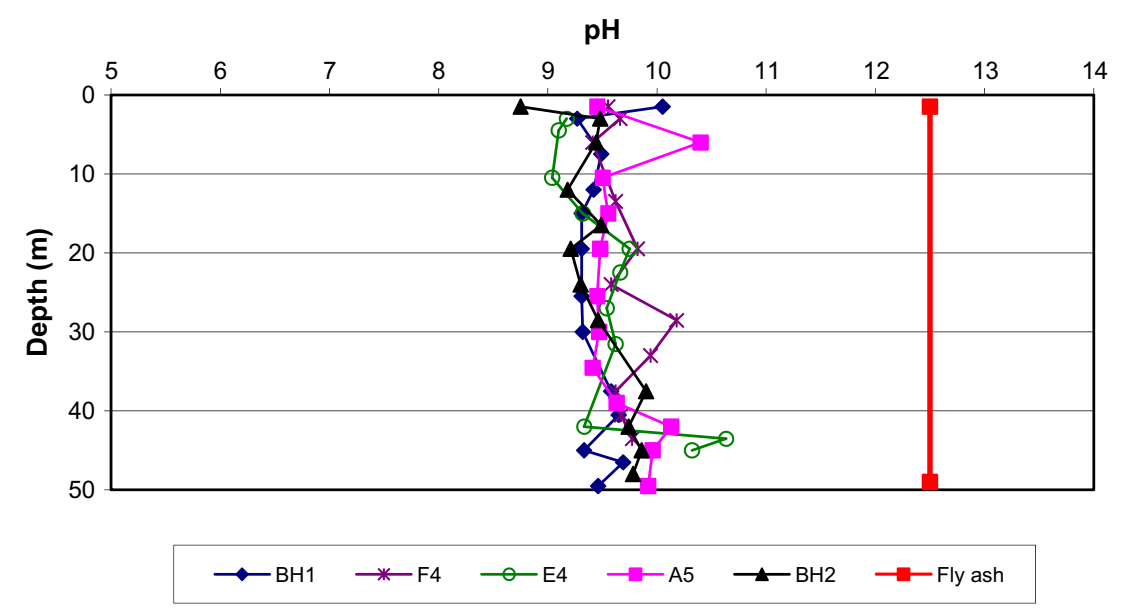

Fig. 5. The pore water pH profile of boreholes.

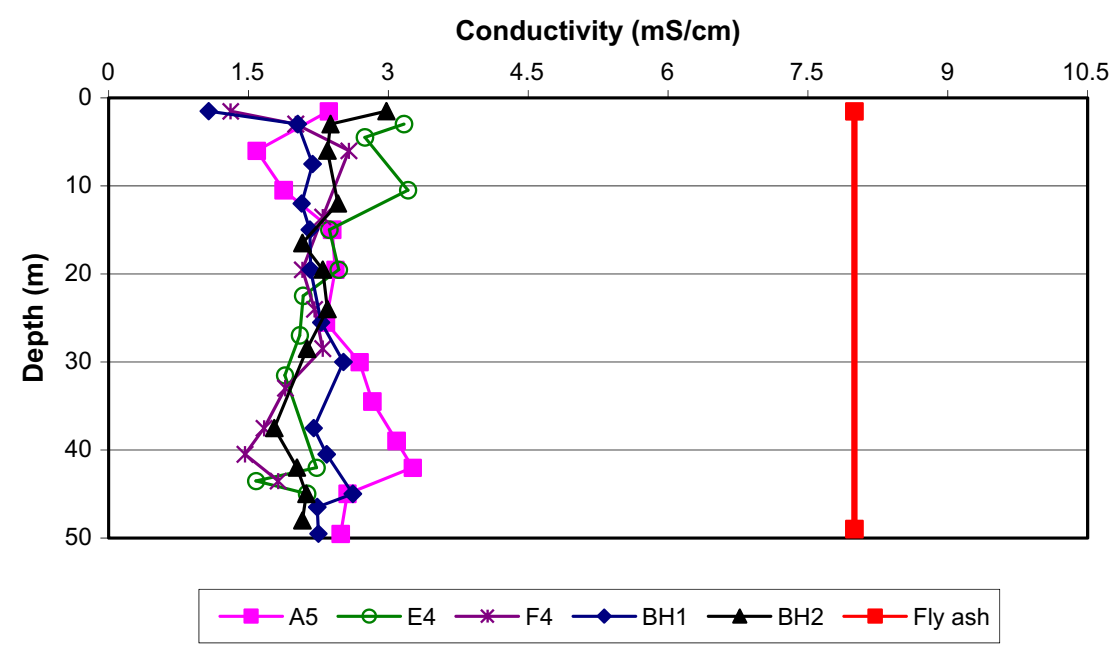

Fig. 6. The pore water EC profile of boreholes.

Table 2

Chemical composition of WFCA and fly ash

\begin{tabular}{lllll}
\hline Component & $\begin{array}{l}\text { Range in WFCA } \\
(\%)\end{array}$ & $\begin{array}{l}\text { Median of WFCA } \\
(\%)\end{array}$ & $\begin{array}{l}\text { Fresh } \\
\text { FCA }^{\mathrm{a}}\end{array}$ & $\begin{array}{l}\text { Fresh fly } \\
\text { ash }\end{array}$ \\
\hline $\mathrm{SiO}_{2}$ & $43.10-43.11$ & 43.10 & 43.31 & 52.29 \\
$\mathrm{Al}_{2} \mathrm{O}_{3}$ & $26.01-30.89$ & 28.68 & 31.09 & 27.51 \\
$\mathrm{Fe}_{2} \mathrm{O}_{3}$ & $1.91-16.62$ & 3.87 & 2.14 & 2.77 \\
$\mathrm{CaO}$ & $8.46-11.05$ & 9.06 & 8.22 & 10.64 \\
$\mathrm{MgO}$ & $1.50-2.33$ & 1.97 & 1.15 & 2.24 \\
$\mathrm{SO}_{3}$ & $1.45-7.44$ & 2.90 & 4.43 & 0.40 \\
$\mathrm{Na}_{2} \mathrm{O}$ & $0.98-3.51$ & 1.98 & 4.48 & 0.71 \\
$\mathrm{~K}_{2} \mathrm{O}$ & $0.71-1.10$ & 0.97 & 0.79 & 0.99 \\
$\mathrm{TiO}_{2}$ & $1.05-1.55$ & 1.46 & 1.38 & 1.59 \\
$\mathrm{SrO}^{\mathrm{BaO}}$ & $0.32-0.55$ & 0.45 & 0.39 & N/A \\
$\mathrm{P}_{2} \mathrm{O}_{5}$ & $0.19-0.35$ & 0.28 & 0.25 & N/A \\
$\mathrm{Cl}$ & $0.66-1.02$ & 0.89 & 0.85 & 0.70 \\
$\mathrm{MnO}$ & $0.19-1.45$ & 0.49 & 1.20 & N/A \\
\hline
\end{tabular}

${ }^{a}$ Fresh FCA refers to fine ash which was sampled from an operational FCAD and dried.

b N/A means the element was not reported.

The observed $\mathrm{pH}$ reduction in this alkaline FCAD is further substantiated by the work of Zevenbergen et al. [13], which was performed on a fresh and eight year old alkaline fly ash dump in India.

The EC data of extracted pore water is erratic at the top and bottom layers of the FCAD and such inhomogeneity is common as also
Table 3

Chemical composition of ash carrier medium (after Mahlaba [29]).

\begin{tabular}{lll}
\hline Component & Units & Ash transport water \\
\hline $\mathrm{pH}$ & - & 12.1 \\
$\mathrm{M}-$ Alkal & $\mathrm{mg} / \mathrm{L}$ as CaCO3 & 1382 \\
$\mathrm{Cl}$ & $\mathrm{mg} / \mathrm{L}$ & 929 \\
$\mathrm{~F}^{-}$ & $\mathrm{mg} / \mathrm{L}$ & 27 \\
$\mathrm{SO}_{4}^{2-}$ & $\mathrm{mg} / \mathrm{L}$ & 2500 \\
$\mathrm{Ca}^{2+}$ & $\mathrm{mg} / \mathrm{L}$ & 450 \\
$\mathrm{Fe}^{2+}$ & $\mathrm{mg} / \mathrm{L}$ & $<1$ \\
$\mathrm{~K}^{+}$ & $\mathrm{mg} / \mathrm{L}$ & 132 \\
$\mathrm{Mg}^{2+}$ & $\mathrm{mg} / \mathrm{L}$ & 3 \\
$\mathrm{Na}^{+}$ & $\mathrm{mg} / \mathrm{L}$ & 1150 \\
$\mathrm{Sr}^{2+}$ & $\mathrm{mg} / \mathrm{L}$ & 27 \\
$\mathrm{Si}^{4+}$ & $\mathrm{mg} / \mathrm{L}$ & 5 \\
$\mathrm{TDS}$ & $\mathrm{mg} / \mathrm{L}$ & 6500 \\
$\mathrm{EC}$ & $\mathrm{mS} / \mathrm{cm}$ & 10
\end{tabular}

TDS $=$ total dissolved solids.

found by other researchers $[12,17,28]$. The results shown in Fig. 6 have the average EC of $2.2 \mathrm{mS} / \mathrm{cm}$ for WFCA whereas fly ash gave $8 \mathrm{mS} / \mathrm{cm}$. The fact that WFCA has three times lower EC than fly ash can be attributed to the formation of hydration products in the case of WFCA [12,27]. 
This observation individually suggests that hydraulic ash disposal with brines provides a potentially better management than a dry ash dump. However, examination of all data will enable the authors to make an encompassing conclusion on the matter.

\subsection{Chemical composition}

The XRF results summarised in Table 2 present the range of chemical composition as oxides of WFCA, fresh FA and fresh fly ash. Comparability of the results validates the use of fly ash as a reference for WFCA besides the brine influence.

The high variation in Fe is caused by the disposal of Fe-based spent catalyst which occurs at irregular intervals whereas additional $\mathrm{S}$ and $\mathrm{Na}$ originate from the brines which transport fine ash $[17,29,30]$. The chemical composition of the brine used as carrier medium in the hydraulic ash disposal is shown in Table 3; where sulphate, sodium, calcium, and chloride are the dominant components. As a result the quantities of $\mathrm{Na}$ and $\mathrm{S}$ present in WFCA was more than $200 \%$ of those originally found in fresh fly ash.

\subsubsection{Classification of elements}

True elemental forms were used for the classification of elements into major $(>1 \%)$ and minor $(0.1-1 \%)$ elements [31]. Silicon, aluminium, calcium, iron, magnesium, and sodium are classified as major elements in WFCA. Minor elements include chlorine, potassium, sulphur, titanium, barium, strontium, and phosphorus. However, the elements of interest are $\mathrm{Si}, \mathrm{Al}, \mathrm{Ca}, \mathrm{Fe}, \mathrm{Mg}, \mathrm{Na}, \mathrm{Cl}$, and $\mathrm{S}$ due to their pertinence to hydration and weathering.

The concentration of most elements remained unchanged between fly ash and WFCA, typical examples being $\mathrm{Al}$ and $\mathrm{Mg}$ while Fe was erratic owing to the disposal of spent Fe-based catalyst as illustrated in Figs. 7 and 8. Only Mg and Fe were used to illustrate the mentioned behaviour.

Fly ash showed a slightly higher concentration (8\%) of calcium than WFCA (6\%), which could indicate that calcium leached from the FCAD. The behaviour shown in Fig. 9 was unexpected because Ca partakes in hydration [27]. Si also shows the same behaviour as $\mathrm{Ca}$, as illustrated in the appended Fig. A2.

Additionally, elements which are predominant in brines, for instance $\mathrm{Cl}$ and $\mathrm{S}$ increased their abundance in WFCA as illustrated in Figs. 10 and 11, respectively. The concentration of $\mathrm{Cl}$ increased from undetectable levels in fly ash to $0.4 \%$ in WFCA. S concentration in fly ash was $0.15 \%$ while that of WFCA showed a gentle decrease from $1.4 \%$ (top) to $0.6 \%$ (bottom) with depth. This decrease suggests that sulphur either leaches at the bottom of the FCAD or results from the deterioration of ash transport water due to desalination in terms of $\mathrm{SO}_{4}^{2-}$.

\subsection{Mineralogy}

Better insight of the weathering process cannot be adequately developed until mineralogy is presented because it controls thermodynamic stability and solubility. XRD analysis was the source of mineralogical data summarised in Table 4. It is observed that significant mineralogical transformation occurred during weathering.

The classification of hydration products was made according to the abundance into major $(>10 \%)$, minor $(1-10 \%)$ and trace $(<1 \%)$ minerals and phases [31,32]. The major phases are amorphous phase, mullite and quartz. Minor mineral phases are magnetite, ettringite, calcite and sillimanite. Trace mineral phases are periclase, analcime, pyrrhotite and hematite. The co-existence of Febearing minerals is ascribed to additional Fe resulting from catalyst

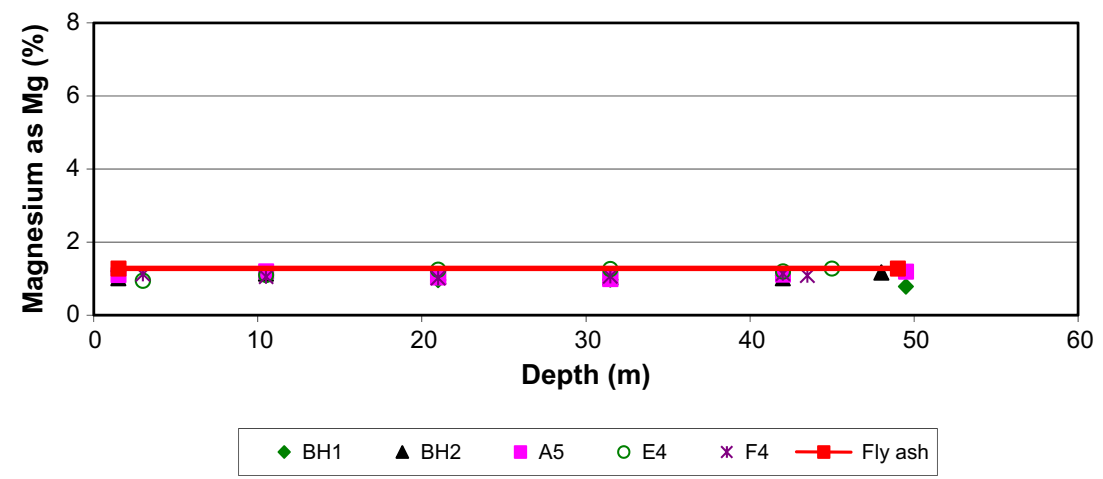

Fig. 7. Illustration of $\mathrm{Mg}$ behaviour.

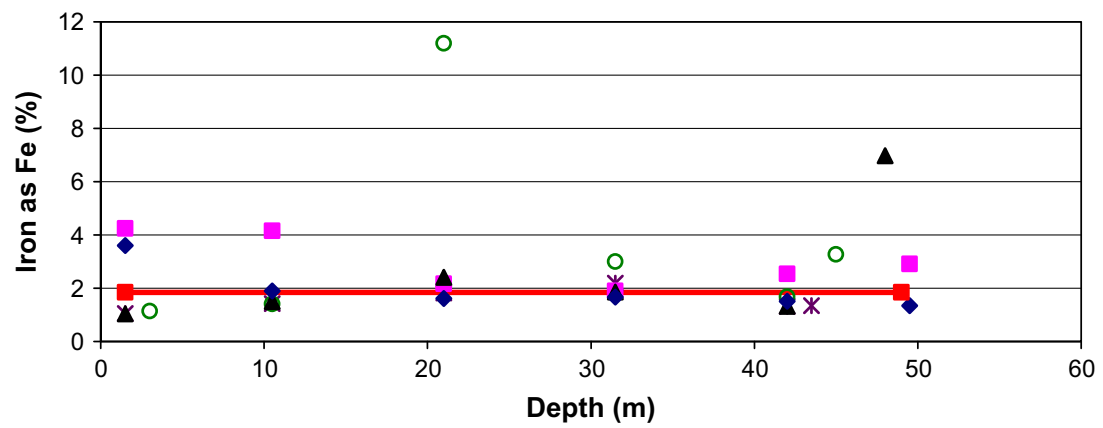

* F4 O E4 $\square$ A5 $\Delta \mathrm{BH}_{2} \bullet \mathrm{BH} 1 \backsim$ Fly ash

Fig. 8. Illustration of Fe behaviour. 


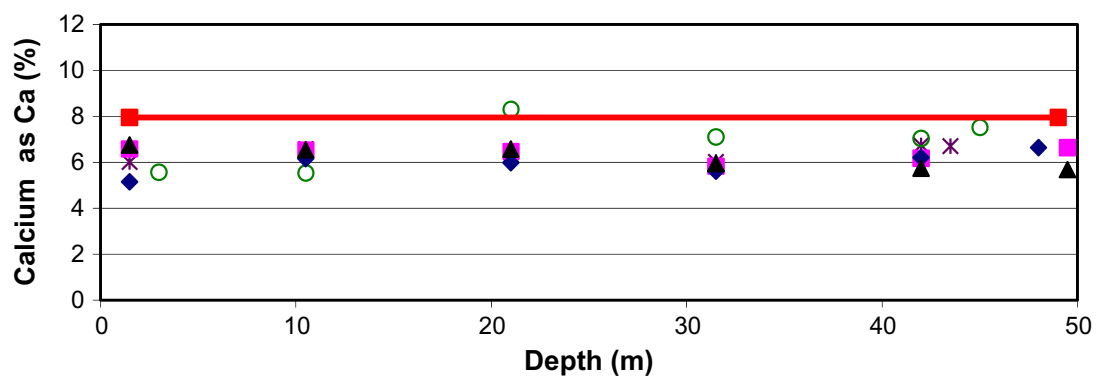

* F4 $\mathrm{F} 4 \quad \square \mathrm{A} 5 \quad \mathrm{BH}_{2} \quad \boldsymbol{B} \mathrm{BH} 1 \rightarrow$ Fly ash

Fig. 9. Profile of $\mathrm{Ca}$ in boreholes.

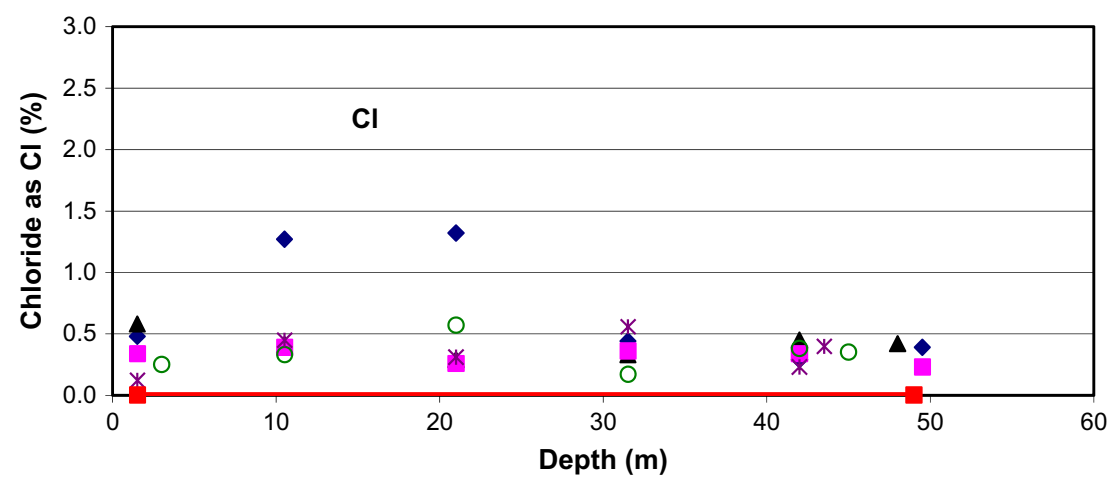

- $\mathrm{BH}_{1} \Delta \mathrm{BH} 2 \quad \mathrm{~A} 5 \quad \mathrm{E} 4 \quad * \mathrm{~F} 4 \rightarrow$ Fly ash

Fig. 10. Profiles showing brine influence on $\mathrm{Cl}$ of WFCA.

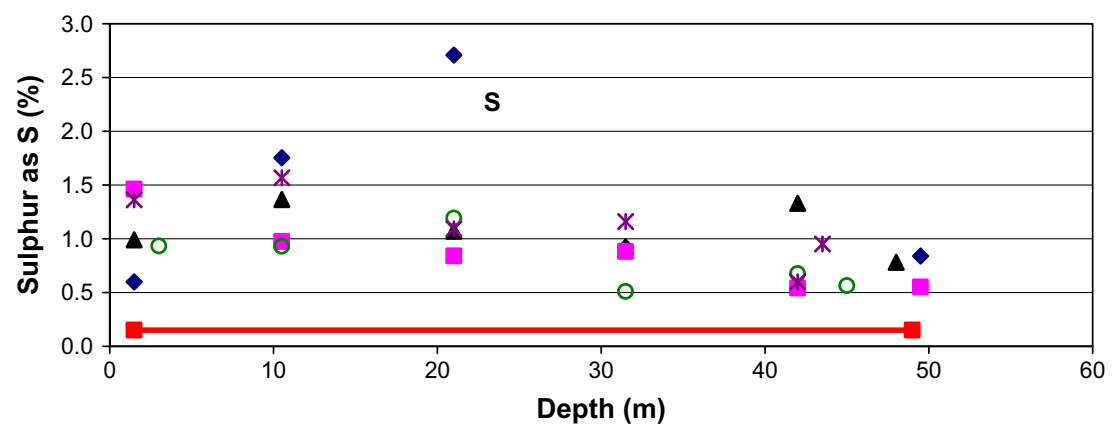

$\begin{array}{lllllll}\mathrm{BH} 1 & \Delta \mathrm{BH} 2 \quad \mathrm{~A} 5 & \mathrm{E} 4 & * \mathrm{~F} 4 & -\end{array}$

Fig. 11. Profiles showing brine influence on $S$ of WFCA.

disposal [17] and higher Fe content showed by XRF (Fig. 8). Periclase was only identified in WFCA and no detectable conversion to brucite $\left(\mathrm{Mg}(\mathrm{OH})_{2}\right)$ occurred despite being expected under normal conditions of hydraulic ash disposal. Other researchers have also made the same observation i.e. existence of periclase in weathered fly ash-water pastes [33]. The identification of analcime (zeolitic Na-bearing mineral) provides the first evidence from mineralogical perspective supporting previous observations that $\mathrm{Na}$ is immobilised in fly ash. The presence of other secondary minerals such as ettringite, calcite, magnetite and pyrrhotite confirms that $\mathrm{Ca}, \mathrm{Fe}$ and $\mathrm{S}$ are also immobilised in the ash dam $[17,27]$. Mooketsi et al. [30] and Mahlaba [29] present the typical brine composition which has contacted fly ash while Fe in the FCAD originates from the disposal of spent catalyst. A typical XRD pattern of WFCA and fly ash is appended in Fig. A3; where the above-mentioned mineralogical differences are demonstrated.

The use of DSC on a characteristic borehole resulted in additional identification of secondary phases, namely, calcium silicate hydrate $(\mathrm{C}-\mathrm{S}-\mathrm{H})$ gel $[34,35]$ and hydrated gehlenite commonly known as Strätlingite $\left(\mathrm{Ca}_{2} \mathrm{Al}_{2} \mathrm{SiO}_{2}(\mathrm{OH})_{10} \cdot 8 \mathrm{H}_{2} \mathrm{O}\right)$ [36]. The importance of $\mathrm{C}-\mathrm{S}-\mathrm{H}$ lies in its contribution to strength and provision of adsorption site for pollutants such as chloride [37,38], which can explain $\mathrm{Cl}$ immobilisation in WFCA without identification of Friedel's salt. Nakamura et al. [39] discovered that only $15 \%$ of $\mathrm{Cl}$ 
Table 4

Summarised XRD results of WFCA and fly ash.

\begin{tabular}{|c|c|c|c|c|}
\hline Component & Chemical formula & $\begin{array}{l}\text { Abundance } \\
(\%)\end{array}$ & $\begin{array}{l}\text { Median } \\
(\%)\end{array}$ & $\begin{array}{l}\text { Fly ash } \\
(\%)\end{array}$ \\
\hline Mullite & $\mathrm{Al}_{6} \mathrm{Si}_{2} \mathrm{O}_{13}$ & $10.2-21.6$ & 18 & 20.53 \\
\hline Quartz & $\mathrm{SiO}_{2}$ & $9.3-13.6$ & 10 & 10.24 \\
\hline Lime & $\mathrm{CaO}$ & $\mathrm{N} / \mathrm{A}$ & $\mathrm{N} / \mathrm{A}$ & 2.22 \\
\hline Calcite & $\mathrm{CaCO}_{3}$ & $2.2-6.3$ & 3 & $\mathrm{~N} / \mathrm{A}$ \\
\hline Periclase & $\mathrm{MgO}$ & $0.3-1.3$ & 0.75 & $\mathrm{~N} / \mathrm{A}$ \\
\hline Magnetite & $\mathrm{FeFe}_{2} \mathrm{O}_{4}$ & $0.1-14.1$ & 2 & $\mathrm{~N} / \mathrm{A}$ \\
\hline Hematite & $\mathrm{Fe}_{2} \mathrm{O}_{3}$ & $0.75-2.0$ & 0.5 & 0.68 \\
\hline Ettringite & $\mathrm{Ca}_{6} \mathrm{Al}_{2}\left(\mathrm{SO}_{4}\right)_{3}(\mathrm{OH})_{12} \cdot 26 \mathrm{H}_{2} \mathrm{O}$ & $0.8-4.5$ & 3 & $\mathrm{~N} / \mathrm{A}$ \\
\hline Sillimanite & $\mathrm{Al}_{2} \mathrm{SiO}_{5}$ & $0.8-2.0$ & 1.5 & $\mathrm{~N} / \mathrm{A}$ \\
\hline Pyrrhotite & $\mathrm{Fe}_{9} \mathrm{~S}_{10}$ & $0.3-0.8$ & 0.3 & $\mathrm{~N} / \mathrm{A}$ \\
\hline Analcime & $\mathrm{NaAlSi}_{2} \mathrm{O}_{6} \cdot \mathrm{H}_{2} \mathrm{O}$ & $0.5-1.6$ & 0.75 & $\mathrm{~N} / \mathrm{A}$ \\
\hline $\begin{array}{c}\text { Amorphous } \\
\text { content }\end{array}$ & $\mathrm{N} / \mathrm{A}$ & $56.5-62.5$ & 60 & 66.3 \\
\hline
\end{tabular}

adsorbed to C-S-H leached out while 65\% leached from Friedel's salt, implying that a FCAD underwent a better Cl-binding mechanism. Moreover, Tishmack and Burns [33] report that Strätlingite can incorporate $S$ as an interlayer ion while Saikai et al. [40] state that Ca can be replaced by alkali metals. The presence of residual amorphous content of approximately 60\% indicates that WFCA can still be utilised as a pozzolan $[41,42]$.

\subsection{Morphology}

SEM analysis shows that fly ash is predominantly made up of spherical particles [33,43] as shown in Fig. 12. In literature researchers elaborate on different types of spherical particles such as cenospheres, plerospheres and spheroids [44,45].
Some FEG-SEM micrographs of WFCA have cenospheres (hollowed spherical particles) as depicted in Fig. 13. This observation agrees with high amorphous content of WFCA from XRD analysis. It further substantiates the postulate made by the present author that WFCA can still be utilised as a pozzolan.

Fig. 14 interestingly shows the micrographs of a complex phase while Fig. 15 shows the presence of crystalline phases some of which are needle-like, hexagonal and platy particles. The presence of the new particle morphologies serves as additional proof that mineralogical transformation occurred in a FCAD [42,46,47], which agrees with XRD and DSC results. Gitari et al. [12] also made a similar observation when comparing SEM micrographs of fly ash and weathered fly ash of ESKOM's Tutuka power station.

A study performed by Campbell [46] on South African fly ashes also confirmed the presence of secondary phases in weathered fly ashes from ESKOM's Matla and Kriel power stations whereas SASOL's weathered fine ash remained indifferent. The SASOL dump investigated by Campbell [46] differs in many aspects from the one being presented in this manuscript; comparison of SASOL operations is beyond the scope of this publication. The particle morphology and particle size of a material play a vital role in determining its engineering behaviour $[9,25,26,48]$.

\section{Conclusions}

The results obtained in this investigation refuted the occurrence of hydraulic sorting in the alkaline FCAD despite being common in gold tailings dams, which can be attributed to physical differences such as particle morphology and density. It was discovered that PSD and specific gravity of WFCA resemble those of fly ash while moisture content increases with depth in the FCAD. FEG-SEM (high resolution) analysis indicates that WFCA has some spherical
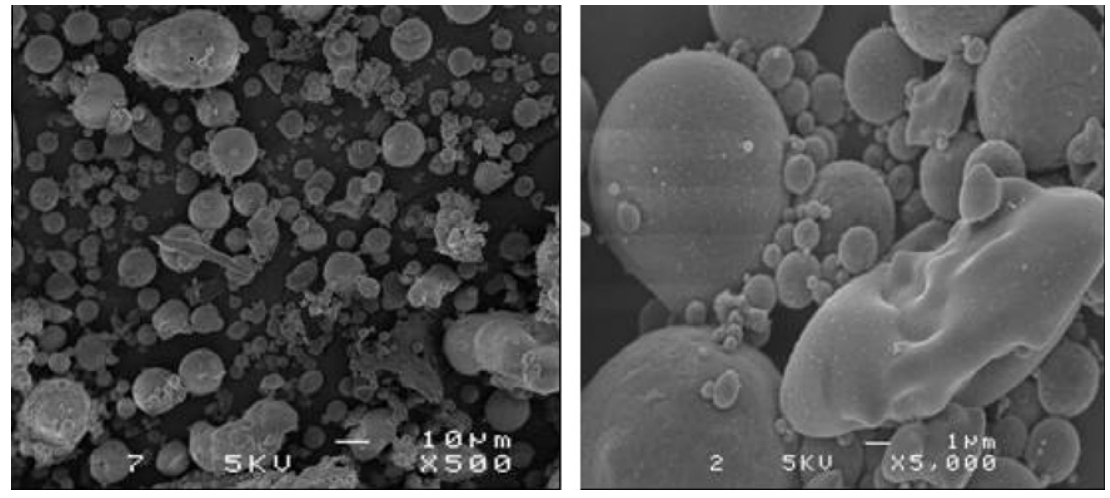

Fig. 12. SEM micrographs of fly ash.
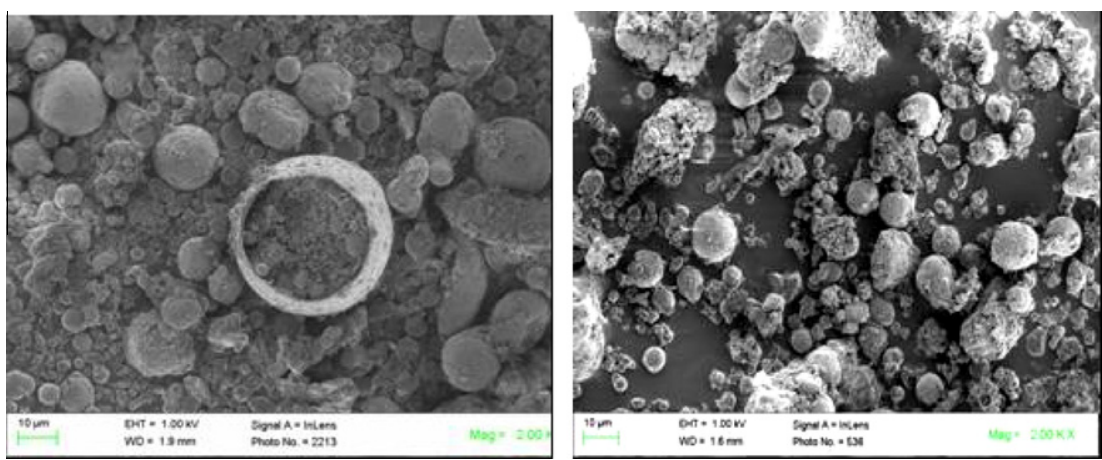

Fig. 13. FEG-SEM micrographs showing sphericity in WFCA. 

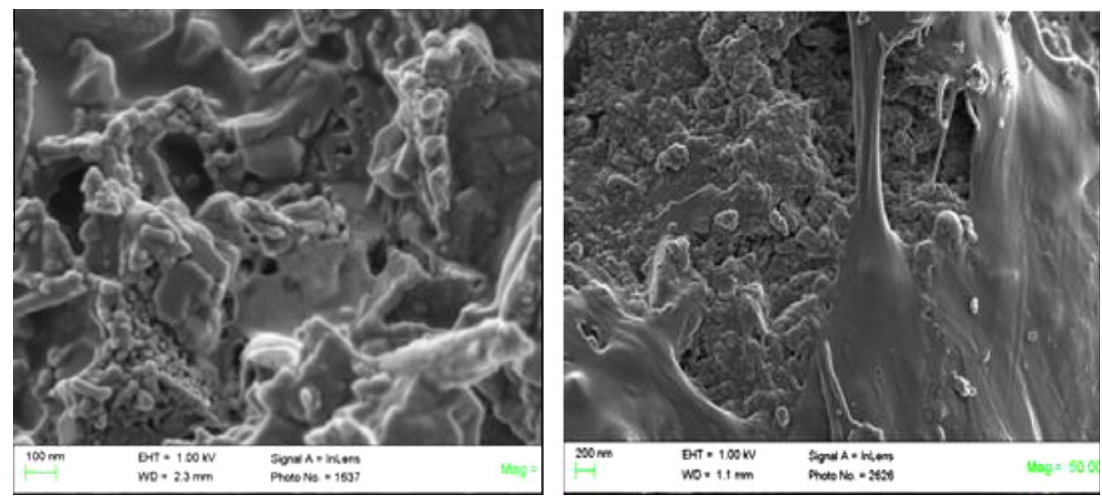

Fig. 14. FEG-SEM micrographs showing the presence of a complex phase in WFCA.
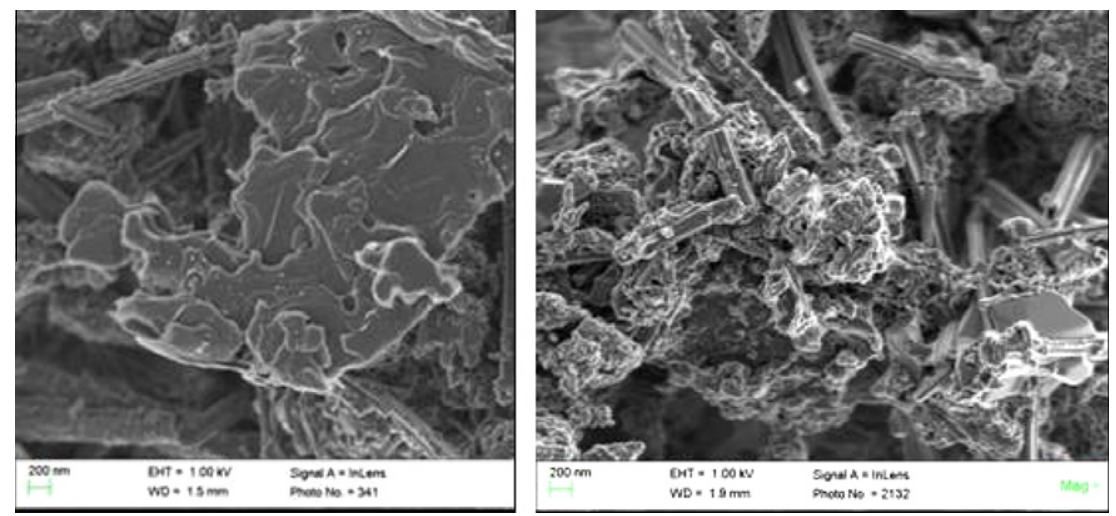

Fig. 15. FEG-SEM micrographs showing new crystalline minerals in WFCA.

particles as found in fly ash in addition to secondary crystalline phases. The presence of cenospheres and similar specific gravity and PSD suggest the utilisation of WFCA. Nevertheless, FEG-SEM analyses agree with XRD and DSC that secondary phases are present in WFCA. This was attributed to chemical weathering according to a $\mathrm{pH}$ reduction of pore water from 12.5 to 9.5 and reduction of M-alkalinity from 1800 to $50 \mathrm{mg} / \mathrm{L}$ as $\mathrm{CaCO}_{3}$. Of particular importance was the identification of analcime, periclase, $\mathrm{C}-\mathrm{S}-\mathrm{H}$ gel and Strätlingite in addition to ettringite, calcite, magnetite, pyrrhotite and sillimanite in WFCA. The environmental significance of C-S$\mathrm{H}$ gel lies in its potential to adsorb impurities such as chloride, which is highly possible in this scenario because $\mathrm{Cl}$ immobilisation was observed without detection of Friedel's salt. It is reported in literature that $\mathrm{C}-\mathrm{S}-\mathrm{H}$ provides a better $\mathrm{Cl}$-binding mechanism than Friedel's salt in terms of leachability. The pore water quality and
XRF indicate that co-disposal of brines with fly ash could be environmentally friendlier than dry ash disposal in terms of overall leaching potential after significant chemical weathering. It is concluded that an alkaline fine ash dam possesses a characteristic profile resembling fly ash except mineralogy and some particle morphology, and hence WFCA stands a good opportunity of utilisation as a pozzolan provided leaching of immobilised salts is combated in the application.

\subsection{Future Work}

- Investigate the leaching potential of weathered fine ash

- Evaluate rehabilitation methods and utilisation opportunities

- Characterise the amorphous content with advanced analytical techniques

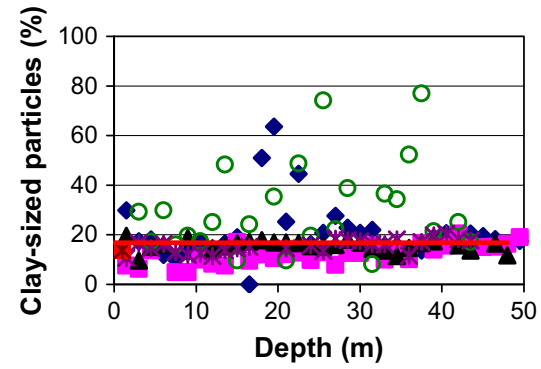

$\bullet \mathrm{BH} 1 \triangle \mathrm{A} 5 \Delta \mathrm{BH} 2$ OE4 *F4 Fly ash

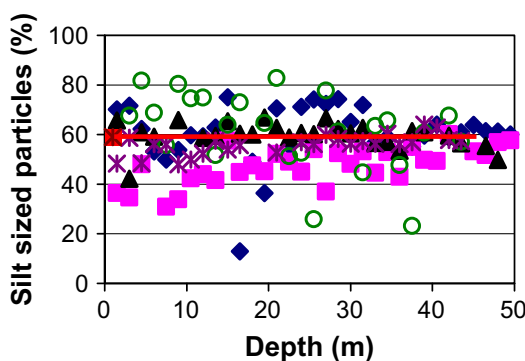

BH1 $\triangle \mathrm{A} 5 \Delta \mathrm{BH} 2$ OE4 *F4 Fly ash

Fig. A1. Illustration of variation of PSD in the FCAD. 


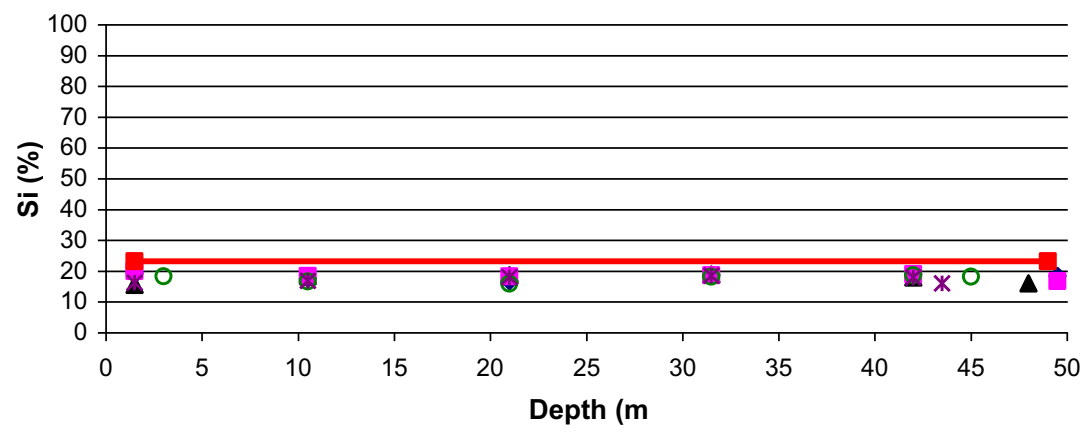

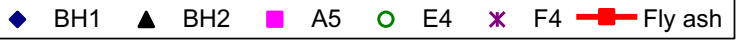

Fig. A2. Profile of Si in boreholes.

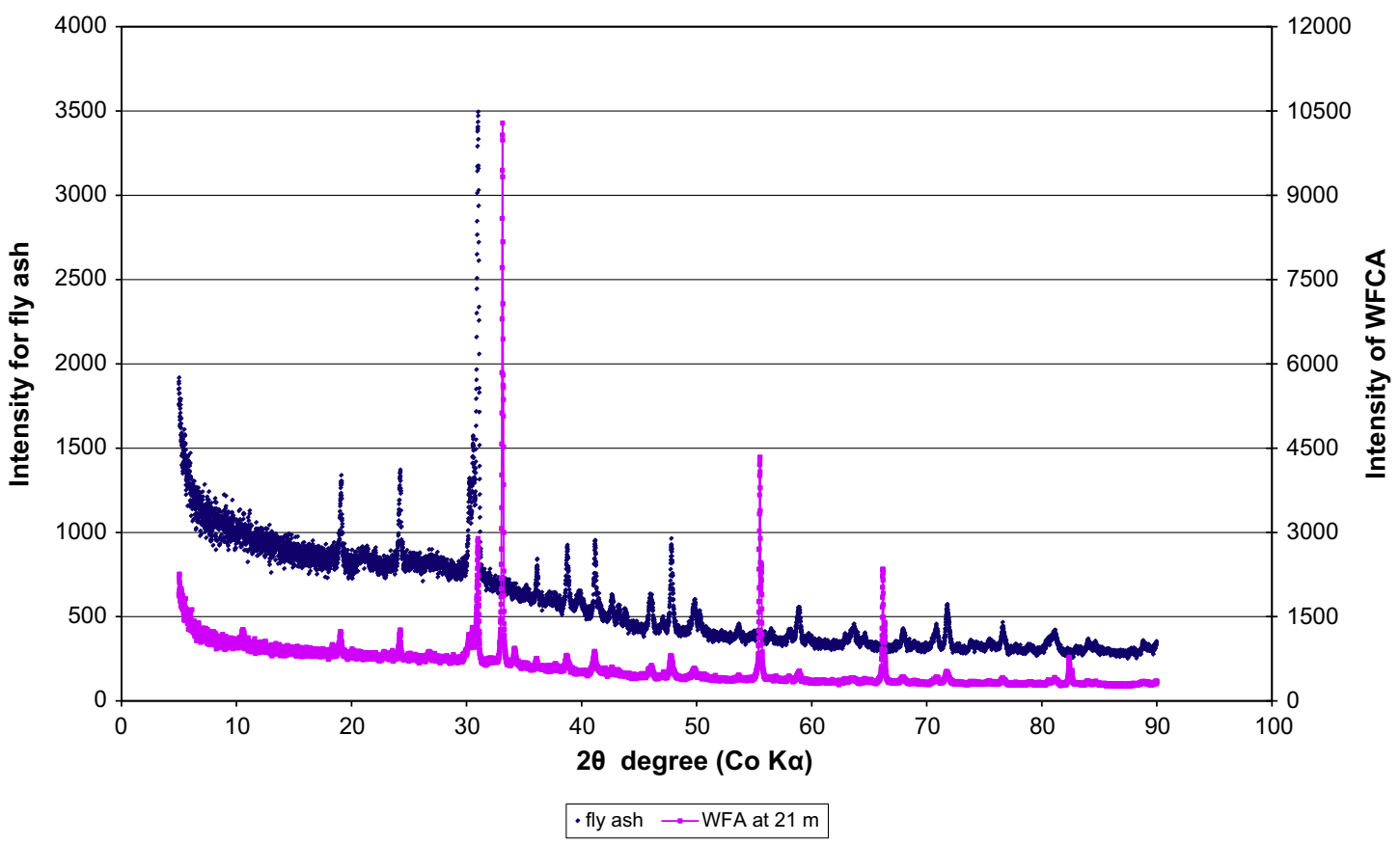

Fig. A3. The XRD patterns of fly ash and a typical WFCA.

\section{Acknowledgements}

The authors would like to thank SASOL Technology R\&D (Pty) Ltd for sponsoring this project and allowing the publication of this work. The University of Pretoria and Richonne Consulting are highly acknowledged for their assistance in setting up experiments and provision of certain analyses. Dr Sabine Verryn (XRD Analytical and Consulting) and Dr Henry Matjie (SASOL) are thanked for their mineralogical inputs. The work was extracted from the PhD project of the lead author.

\section{Appendix A}

Figs. A1-A3.

\section{References}

[1] Cheng C-M. Leaching of coal combustion products: field and laboratory studies. PhD thesis. The Ohio State University; 2005.

[2] Mahlaba JS, Pretorius PC. Exploring paste technology as a co-disposal option for fly ash and brines. In: Proc the 9th international seminar on paste and thickened tailings. Limerick, Ireland; 3-7 April, 2006.
[3] Fernández-Pereira C, Galiano YL, Rodríguez-Piñero MA, Vale J, Querol X. Utilisation of zeolitised coal fly ash as immobilising agent of metallurgical waste. J Chem Technol Biotechnol 2002;77:305-10.

[4] Shang JQ Wang $\mathrm{H}$. Coal fly ash contaminant barrier for reactive mine tailings. <http://www.flyash.info/2005/52sha.pdf>; 2005 [accessed 25.01.07].

[5] Ilgner $\mathrm{JH}$. Cost-effective utilisation of fine and coarse ash to maximise underground coal extraction and to protect the environment. In: Proc of coal indaba conference 2002. Fossil Fuel Foundation of Africa, Secunda, South Africa; 16 October, 2002.

[6] Kruger RA, Surridge AKJ. Predicting the efficacy of fly ash as a soil ameliorant. World of coal ash conference. Lexington, USA; 4-7 May, 2009. <http:// www.flyash.info/>.

[7] Pandian NS. Fly ash characterization with reference to geotechnical applications. J Indian Inst Sci 2004;84:189-216.

[8] Gitari WM, Petrik LF, Etchebers O, Key DL, Iwuoha E, Okujeni C. Utilization of fly ash for treatment of coal mines waste water: solubility controls on major inorganic contaminants. Fuel 2008;87:2450-62.

[9] Kearsley EP, Wainwright PJ. The effect of fly ash properties on concrete strength. J South African Inst Civil Eng 2003;45:19-24.

[10] Kruger RA, Krueger JE. Historical development of coal ash utilization in South Africa. <http://www.flyash.info/2005/204kru.pdf>; 2005 [accessed 16.07.07].

[11] Haynes RJ. Reclamation and revegetation of fly ash disposal sites - challenges and research needs. J Environ Manage 2009;90:43-53.

[12] Gitari WM, Fatoba OO, Nyamihingura A, Petrik LF, Vadapall VKR, Nel J et al Chemical Weathering in a dry ash dump: An Insight from physicochemical and mineralogical analysis of drilled cores. World of coal ash conference. Lexington, USA; 4-7 May, 2009. <http://www.flyash.info/>. 
[13] Zevenbergen C, Bradley JP, van Reeuwijk LP, Shyam AK. Clay formation during weathering of alkaline coal fly ash. International ash utilisation symposium, centre for applied energy research. University of Kentucky; 1999 [paper no. 14].

[14] Saresh IV, Padmakar C, Padmakaran P, Murthy MVRL, Raju CB, Yadava RN, et al. Effect of pond ash on ground water quality: a case study. Environ Manage Health 1998;9(5):200-8.

[15] Baba A, Usmen MA. Effect of fly ash from coal-burning electrical utilities on the ecosystem and utilisation of fly ash. Groundwater Ecosyst 2006:28.

[16] Lee S-J, Chan H-C, Um N, Han G-C, Ahn J-W. Characterisation of coal pond ash for reutilisation. International symposium on materials processing KIGAM, Daejeon, Korea; 20 April, 2007.

[17] Koch EW. An investigation of the chemistry involved in the mixing of an industrial effluent with fine ash. MSc thesis. University of Stellenbosch; December 2002.

[18] Sarkar R, Singh N, Das SK. Effect of addition of pond ash and fly ash on properties of ash-clay burnt bricks. Waste Manage Res 2007;25:566-71.

[19] Matjie RH, Li Z, Ward CR, French D. Chemical composition of glass and crystalline phases in coarse coal gasification ash. Fuel 2008;87:857-69.

[20] Matjie RH, van Alphen C. Mineralogical features of size and density fractions in Sasol coal gasification ash, South Africa and potential by-products. Fuel 2008;87:1439-45.

[21] ASTM D 2216-98. Standard test methods for laboratory determination of water (moisture) content of soil and rock by mass. ASTM International; 1998.

[22] ASTM D4972-01. Standard test methods for ph of soils. ASTM International; 2001.

[23] ASTM D 422-63. Standard test methods for particle size analysis for soils. ASTM International; 2002.

[24] Glasser FP. Coal combustion wastes: characterisation, reuse and disposal. In: Gieré R, Stille P editors. Energy, waste and the environment: a geochemical perspective, vol. 236. Geological Society: London, Special Publications; 2004. p. 211-22.

[25] Vermeulen NJ. The composition and state of gold tailings. PhD thesis. South Africa: University of Pretoria; April 2001.

[26] Chang HN. The effect of fabric on the behaviour of gold tailings. PhD thesis. South Africa: University of Pretoria; April 2009.

[27] Donahoe RJ. Secondary mineral formation in coal combustion byproduct disposal facilities: implications for trace element sequestration. In: Gieré R, Stille P editors. Energy, waste and the environmental: a geochemical perspective. geological society, vol. 236. London, Special Publications; 2004. p. 641-58.

[28] Fourie AB. Liquefaction potential of surface deposits of high-density thickened tailings. In: Proc, paste, 9th international seminar on paste and thickened tailings, Limerick, Ireland; 3-7 April 2006. p. 107-15.

[29] Mahlaba JS. Evaluation of paste technology to co-dispose of ash and brines at Sasol Synfuels complex. MSc (Eng) dissertation. South Africa: University of the Witwatersrand; 2007.

[30] Mooketsi OI, Ginster M, Matjie RH, Riedel KJ. Leachate characteristics of ash residues from laboratory-scale brine encapsulation simulation process. World of coal ash (WOCA). Kentucky, USA; 2007.
[31] Vassilev SV, Vassileva CG. A new approach for the classification of coal fly ashes based on their origin, composition, properties, and behaviour. Fue 2007;86:1490-512.

[32] van Alphen C. Factors influencing fly ash formation and slag deposit formation (slagging) on combusting a South African pulverised fuel in a 200 MWe boiler. PhD thesis. South Africa: University of the Witwatersrand; 2005.

[33] Tishmack JK, Burns PE. The chemistry and mineralogy of coal and coa combustion products. In: Gieré R, Stille $\mathrm{P}$ editors. Energy, waste and the environmental: a geochemical perspective. geological society, vol. 236 London, Special Publications; 2004. p. 223-46.

[34] Ylmén R, Jäglid U, Steenari B-M, Panas I. Early hydration and setting of Portland cement monitored by IR, SEM and Vicat techniques. Cem Concr Res 2009;39:433-9.

[35] Colleman NJ, Mcwhinnie WR. The solid state chemistry of metakaolin-blended ordinary Portland cement. J Mater Sci 2000;35:2701-10.

[36] Matschei T, Lothenbach B, Glasser FP. Thermodynamic properties of Portland cement hydrates in the system $\mathrm{CaO}-\mathrm{Al}_{2} \mathrm{O}_{3}-\mathrm{SiO}_{2}-\mathrm{CaSO}_{4}-\mathrm{CaCO}_{3}-\mathrm{H}_{2} \mathrm{O}$. Cem Concr Res 2007;37:1379-410.

[37] Beaudoin JJ, Ramachandran VS, Feldman RF. Interaction of chloride and C-S-H. Cem Concr Res 1990;20:875-83.

[38] Sumranwanich T, Tangtermsirikul S. Time-dependent chloride binding capacity of various types of cement pastes. Sci Asia 2004;30:127-34.

[39] Nakamura A, Nishizawa E, Ohba Y, Daimon M. Sorption of chloride-ion, sulfate-ion and phosphate-ion, in calcium silicate hydrates. J Chem Soc Jpn, Chem Indus Chem 1999;6:415-20.

[40] Saikai N, Kato S, Kojima T. Thermogravimetric investigation on the chloride binding behaviour of MK-lime paste. Thermochim Acta 2007;444:16-25.

[41] Ward CR, French D. Determination of glass content and estimation of glass composition in fly ash using quantitative X-ray diffractometry. Fuel 2006;85:2268-77.

[42] Yeheyis MB, Shang JQ, Yanful EK. Chemical and mineralogical transformations of coal fly ash after landfilling. WOCA conference. Lexington, USA; 4-7 May, 2009. <http://www.flyash.info>.

[43] Medina A, Gamero P, Almanza JM, Vargas A, Montoya A, et al. Fly ash from a Mexican mineral coal. II. Source of $\mathrm{W}$ zeolite and its effectiveness in arsenic (V) adsorption. J Hazard Mater 2010;181:91-104.

[44] Vassilev SV, Vassileva CG. Mineralogy of combustion wastes from coal-fired power stations. Fuel Process Technol 1996;47:261-80.

[45] Chancey RT, Stutzman P, Juenger MCG, Fowler DW. Comprehensive phase characterisation of crystalline and amorphous phases of a class F fly ash. Cem Concr Res 2010:40:146-56.

[46] Campbell AE. Chemical, physical and mineralogical properties associated with the hardening of some South African fly ashes. MSc dissertation. University of Cape Town; January 1999.

[47] Zevenbergen C, van Reeuijk LP, Bradley JP, Bloemen P, Comans RNJ Mechanism and conditions of clay formation during natural weathering of MSWI bottom ash. Clay Clay Miner 1996;44(4):546-52.

[48] Fester VG, Slatter PT, Vadapalli VRK, Petrik L. Use of fly ash to treat acid mine drainage before use in backfill. In: Proc the 11th seminar on paste and thickened tailings. Kasane, Botswana; 5-9 May, 2008. 